\title{
Using Technology in Gifted and Talented Education Classrooms: The Teachers' Perspective
}

\author{
Susan L. Zimlich \\ Southeastern Louisiana University, Hammond, Louisiana, USA
}

susan.zimlich@selu.edu

\begin{abstract}
Technology skills are assumed to be a necessity for college and career success, but technology is constantly evolving. Thus, development of students' technology skills is an on-going and persistent issue. Standards from the Partnership for $21^{\text {st }}$ Century Skills and the International Society for Technology in Education encourage educators to teach skills that help students adapt to changing working environments. These skills resemble the National Association for Gifted Children's program and teacher preparation standards. Descriptive research about what is already occurring in classrooms has been done, but the information is frequently limited to a list of activities. A qualitative multi-case phenomenological study of six Alabama teachers of the gifted examined how they use and shape technology experiences with students, and promote student learning of $21^{\text {st }}$ century skills. The teachers were chosen for the case study due to their reputation as teachers skilled in using technology with students. Lesson plans, interviews, and observations were used to discover themes between the teachers. Findings from the research indicate that educational technology use with students is shaped by factors such as teacher attitudes and expertise, available equipment and support, pedagogical decisions related to working with technology, and the particular student group participating in the technology use.
\end{abstract}

Keywords: Educational technology, gifted, qualitative study, elementary education

\section{Introduction}

Knowledge is no longer enough; teachers must integrate $21^{\text {st }}$ century skills (Partnership for $21 \mathrm{st}$ Century Skills and American Association of Colleges of Teacher Education, 2010). In addition to mastery of content, $21^{\text {st }}$ century skills include not only digital literacy, but also skills such as adaption, initiative, management, collaboration, innovation, and global thinking (Partnership for 21 st Century Skills, 2004). These $21^{\text {st }}$ century skills are measured by fluency in skills such as identifying problems, locating relevant information, and delivering a thoughtful product or response (Eshet-Alkalai, 2004; Housand, 2011).

Material published as part of this publication, either on-line or in print, is copyrighted by the Informing Science Institute. Permission to make digital or paper copy of part or all of these works for personal or classroom use is granted without fee provided that the copies are not made or distributed for profit or commercial advantage AND that copies 1) bear this notice in full and 2) give the full citation on the first page. It is permissible to abstract these works so long as credit is given. To copy in all other cases or to republish or to post on a server or to redistribute to lists requires specific permission and payment of a fee. Contact Publisher@,InformingScience.org to request redistribution permission.
The similarity of goals between educators of the gifted and talented $(\mathrm{G} / \mathrm{T})$ and technology educators suggest that teachers trained in $\mathrm{G} / \mathrm{T}$ education will teach in ways that support the 21 st century learning goals of the P21 Framework and the National Education Technology Standards (NETS) indicators (International Society for Technology in 
Education, 2010; National Association for Gifted Children, 2010; Partnership for 21st Century Skills, 2004).

In Alabama at the elementary school level, teachers of G/T typically teach in enrichment classrooms. These teachers have smaller class sizes and more freedom in determining content. Additionally, the researcher had experience in the field of education of the gifted. Thus this study focused primarily on the ways G/T teachers in elementary schools in Alabama develop students' technology, media, and information literacy.

The amount and use of technology may vary from school to school and even from classroom to classroom; however, more and more teachers rely on technology, both to support lesson planning and administrative duties, as well as for instruction (Bebell, Russell, \& O'Dwyer, 2004). However, just because a classroom contains technology does not mean it is being used in meaningful ways, either by the teacher or by the students (Bebell, O'Dwyer, Russell, \& Hoffmann, 2010; Bebell et al., 2004). Some teachers actively utilize technology with students, which can impact both what is being taught and how it is taught (Koehler \& Mishra, 2005). Effective utilization of technology includes activities such as having students do research on the Internet, create presentations, publish using Web 2.0 technologies, and other learning tasks where students are actively using technology rather than passively watching teachers use technology. Many different varieties of technology have been adapted for use in educational settings. Some technologies may not have originally been developed with classrooms in mind, but teachers have found ways to use them effectively in the classroom. Therefore in this paper the terms technology and educational technology will be considered synonymous.

According to the Technological Pedagogical Content Knowledge theory of Koehler and Mishra (2005), the use of technology influences the teaching of content. Interaction between the characteristics of technology and the structure of the content directs examples used in teaching content (Bielefeldt, 2012; Koehler \& Mishra, 2005). Also, a teacher's knowledge of the content area directs the technologies selected and the pedagogy used. Finally, since the teacher's understanding of technology, content, and pedagogy interact, the teacher's expertise with pedagogy also will dictate the use of technology and the content being taught (Angeli \& Valanides, 2009). Thus, according to Koehler and Mishra's (2005) Technological Pedagogical Content Knowledge theory, it is in the overlap between knowing the content, knowing appropriate pedagogy, and knowing ways that technology can be used that the most powerful teaching occurs.

A growing body of research sheds light on various implementations of educational technology, but such research needs almost constant re-evaluation to keep up with the non-stop development of technology. Examples of technology implementations include using technology that supports delivery of content such as guided notes (Boon, Fore, \& Rasheed, 2007; Ysseldyke, Tardrew, Betts, Trill, \& Hannigan, 2004), interactive games (Clarke-Midura \& Dede, 2010; Ke, 2008; Tünzün, 2007), and to provide other resources such as additional texts, mentors or differentiated content (Couse \& Chen, 2010; Dove \& Zitkovich, 2003; Glassman \& Burbidge, 2014; Olszewski-Kubilius \& Lee, 2004; Reid \& Roberts, 2006)). On occasion, technology is used to develop collaboration (Basham et al., 2010; Dove \& Zitkovich, 2003; Taylor \& Duran, 2006) or classroom community (Clark, Logan, Luckin, Mee, \& Oliver, 2009; Wighting, 2006). Sometimes technology can be used as an intervention to support struggling students by providing additional study materials (Siegle \& Foster, 2001), organizational tools (Myles, Ferguson, \& Hagiwara, 2007), or individual instant support (Mostow, Nelson-Taylor, \& Beck 2013). Students may be assessed through products created by students using technology (Basham, Meyer, \& Perry, 2010; Nugent, Barker, Grandgenett, \& Adamchuk, 2010), through technology used to deliver content and assessments at the appropriate instructional level for individual students (Ysseldyle et al., 2004), or through ways to use technology to share products with a wider audience (Dove \& Zitkovich, 2003). Technology can be used to help develop students' critical thinking and prob- 
lem-solving skills (Clarke-Midura \& Dede, 2010; Ge, Thomas, \& Greene, 2006; Glassman \& Burbidge, 2014; Nugent et al., 2010; Tünzün, 2007).

The research about teachers' use of technology and students' perceptions of using technology in classrooms, as well as the researcher's knowledge of G/T education led to an exploratory study about how $\mathrm{G} / \mathrm{T}$ teachers known to have technology-rich classrooms use technology with students. A qualitative phenomenological case study was conducted and the results are discussed. This paper provides a literature review and discussion of the standards and framework that shaped the development of the research question. Then the research methods, data, and findings are shared and discussed. Finally, limitations, implications, and the need for further research are addressed.

\section{Literature Review}

A body of research is developing around technology in education. Teachers implement technology in varying degrees (Ritzhaupt, Dawson, \& Cavanaugh, 2012). The use of technology by teachers is influenced by many factors.

\section{Pedagogy}

Pre-service teachers appear most likely to use technologies with which they are familiar. Faculty modeling of technology encourages pre-service teachers to adopt creative and authentic ways to incorporate technology in their own classrooms (National Council for Accreditation of Teacher Education, 2012; Rowley, Dysard, \& Arnold, 2005; Snider, 2002; Wilson, Wright, \& Stallworth, 2003). Teacher education programs that incorporate a variety of technologies including teachercentered, child-centered, and task-centered technologies, help pre-service teachers become familiar with different technologies (Bucci, 2003).

According to Ritzhaupt, Dawson, and Cavanaugh (2012), factors such as number of years teaching, level of education of the teacher, and classroom factors influence whether in-service teachers use educational technology. In-service teachers' use of technology, either overall technology use such as for administrative duties or for having students use technology, decreases in correlation with the number of years spent teaching in a classroom, but increases with the level of professional education, either college courses or professional development. Access to technology in the classroom influences teachers' technology use (Chai, Koh, \& Tsai, 2013; Ritzhaupt et al., 2012), but grade level, number of students, and the level of technology support did not influence overall usage of technology. However, class size, and grade level impacted the frequency with which technology was used to support instruction and whether the students were allowed to use technology. Frequency of use increased, as did allowing students to use technology as the length of time a teacher has been using technology increased (Ritzhaupt et al., 2012), a finding which could be explained by teachers moving from apprehension about increased workload during the initial phases of introducing a new technology to thinking about how to use the new technology to support student learning as teachers begin to adapt to the new technology (Donovan, Hartley, \& Strudler, 2007; Glassman \& Burbidge, 2014). Additionally, there was an inverse relationship between the frequency of technology use by the teacher versus the frequency of technology use by students (Bielefeldt, 2012).

Technology use by teachers can be influenced by whether the teacher perceives the primary purpose of schools "as places for cultural reproduction and the emphasis on paper-and-pencil tests and examinations" (Chai et al., 2013, pp. 46) or a place where the teacher is allowed "flexibility and creativity" (Chai et al., 2013, pp. 46). Teachers' perceptions of the usefulness of educational technologies are linked to the conditions and attitudes at the schools in which they teach (Hodges $\&$ Prater, 2014; Perrotta, 2013). The use of educational technology also requires teachers to be willing to shift classroom practice from teacher-centric to student-centric teaching techniques 
(Glassman \& Burbidge, 2014; Lowther, Inan, Ross, \& Strahl, 2012). Teachers were motivated to use technologies that they thought students would need to use in the future and technologies that the teachers thought the students would find engaging or motivating (Hodges \& Prater, 2014).

Teachers do not embrace technology just because it exists, but because it is user-friendly, flexible, engaging, useful, and results-oriented (Baule, 2007). For some teachers, technology is blended seamlessly with their instruction (Clausen, 2007), but for others, many aspects of planning and organization make technology enhancements problematic (Garcia \& Rose, 2007). Whether a teacher chooses to use technology or not, it is clear that the teacher has control over use of technology in school and related to school work for students (Kimball, 2001, Ritshaupt, Dawson, \& Cavanaugh, 2012).

\section{Knowledge of the Learner}

Student issues include access to technology (Ba, Tally, \& Tsikalas, 2002; Neuman \& Celano, 2006), use of technology (Neuman \& Celano, 2006), attitudes toward technology (Boon et al., 2007; Dove \& Zitkovich, 2003; Johnsen, Witte, \& Robins, 2000), technology's impact on achievement and motivation (Abelman, 2007; Boon et al., 2007; Siegle \& Foster, 2001), and the potential for technology to meet students' individual learning needs (Boon et al., 2007; Siegle \& Foster, 2001).

Students may have broad or limited technology choices depending on the specificity with which teachers construct assignments (Ritzhaupt et al., 2012). Students' zones of proximal development, with respect to technology, may or may not match what the teacher is asking the students to do. Some students require extra technical help. In these cases, the use of technology interferes with learning content. Other students are so proficient that they can direct the computer to do the task intended to promote learning. Teachers must have a plan to address students who are technology novices and students who are technology experts.

Technology use may not have a big impact on student learning compared to student learning without technology (Lowther et al., 2012; Lye, Abas, Tay, \& Saban, 2012), but students who use technology indicate that it is a positive experience for them (Lye et al., 2012). They believe that they learn more in both depth and breadth of a content area than those who do not use it (Boon et al., 2007; Dove \& Zitkovich, 2003; Garcia \& Rose, 2007; Kimball, 2001; Siegle \& Foster, 2001; Wighting, 2006; Wong et al., 2006; Ysseldyke et al., 2004). Students, and in particular G/T students, learn more when using technology than without technology (Siegle \& Foster, 2001). Student learning is reinforced and enhanced through software that aids the development of study skills and/or provides course related materials (Boon et al., 2007; Olszewski-Kubilius \& Lee, 2004; Siegle \& Foster, 2001; Ysseldyke et al., 2004). The same material presented by the same teacher can produce different levels of learning, depending on the availability and use of technology by the students (Siegle \& Foster, 2001).

Computer technology has revolutionized public and private spaces, including the educational environment of schools. Technology has moved the emphasis from information to information management. Students who are in classrooms with technology initiatives in place perform better in areas related to $21^{\text {st }}$ century skills and knowledge than in classrooms without as much technology integration (Lowther et al., 2012).

Teachers have access to many resources via the Internet to support their planning and teaching. The availability of software that can provide direct individual feedback and deliver content practice within an individual student's zone of proximal development means that there are more resources for teachers to differentiate instruction (Kang, Heo, Jo, Shin, \& Seo, 2010; Lye et al., 2012; Ysseldyke et al., 2004). Technology can help with research, but can also be used to create products that demonstrate learning (Dove \& Zitkovich, 2003; Johnsen et al., 2000; Savannah R- 
III School District, 2001; Siegle \& Foster, 2001; Taylor \& Duran, 2006; Wong et al., 2006). The ready access to Web 2.0 publishing creates the possibility of providing more authentic learning environment (Kang et al., 2010). Thus, technology can appear in the delivery of content, the process of learning, and product or assessments to demonstrate learning.

\section{Professionalism}

Schools and school districts can either encourage or discourage use of technology through their planning and/or policies, the support services they provide for technology implementation (Clausen, 2007; Donovan et al., 2007), the presence or lack of an organized and comprehensive plan to integrate technology, and the general attitude toward technology and its use (Clausen, 2007).

National professional organizations have developed standards related to technology and $21^{\text {st }}$ century skills. It is the standards from the Partnership for $21^{\text {st }}$ Century Skills (P21), the International Society for Technology in Education (ISTE), and the National Association for Gifted Children (NAGC) that have created the framework for this research. The standards inform how technology should be used with the knowledge of the learner in mind, how teachers use their knowledge of pedagogy to make decisions about teaching with technology, and how administrative decisions and professional development influence teachers' decisions about using technology. Thus what follows is an introduction to the P21, ISTE, and NAGC standards.

\section{Rationale/Theoretical Framework}

A broad definition of technology is any modification that aids in completing tasks (National Assessment Governing Board, n.d.). However, in the context of this study the modifications will specifically relate to electronic devices that allow transfer of information and products between people and locations (Katic, 2008). The use of computers and other equipment with a computer chip in it; including hardware, such as laptops, desktop computers, SMART Boards, iPods or global positioning systems, and software such as word processing, spreadsheet files, presentations, multiplayer video games and other programs will be considered as modifications that are labeled as technology.

\section{International Society for Technology in Education}

The purpose of ISTE (2010) is to focus on instructional technology in kindergarten through twelfth grade, as well as in teacher preparation programs. The ISTE standards do not focus on a specific skills checklist, but rather on general attitudes and broad abilities. The vision of ISTE is that technology is a tool supporting development and expression of dispositions for a technologically literate citizenry. National Education Technology Standards (NETS) for students, teachers, and administrators are each linked at http://www.iste.org/standards.aspx. The NETS for students contains broad disposition goals such as:

- creativity and innovation;

- critical thinking, problem solving, and decision making;

- communication and collaboration.

These standards are further elaborated with examples. An example is that Standard 4, critical thinking, problem solving, and decision making, are about authentic problems and solution finding. The standards are punctuated by verbs such as: locate, organize, apply, contribute, manage, create, evaluate, and so forth. 


\section{Partnership for $21^{\text {st }}$ Century Skills}

A working relationship between the U.S. Department of Education, several technology related businesses, the National Education Association, and a few interested individuals makes up P21. The goal of this relationship is to help educate future citizens with skills relevant in a workplace constantly being transformed by technology. Available at the website http://www.p21.org/ourwork/p21-framework, the Framework for $21^{\text {st }}$ Century Learning contains student outcomes and a listing of support systems. Like the NETS standards, the framework promotes broad aptitudes meant to strengthen the abilities of students who will live and work in a dynamic, technologyfilled world (International Society for Technology in Education 2010; Partnership for 21st Century Skills, 2004). The P21 Outcomes for students include broad areas with subcategories, including:

- Life and Career skills: dispositions such as leadership, productivity, social savvy, goal setting, and adaptation.

- Information, Media, and Technology skills: fluency in gathering and using information, and being able to use media and technology effectively.

- Learning and Innovation: critical thinking, communication, collaboration, and creativity.

- Core Subjects and $21^{\text {st }}$ Century Themes: traditional content areas, plus global awareness and literacy in financial, civic, health, and environmental areas.

The P21 Framework contains the idea that student outcomes, content, pedagogy, learning environments, and professional development should be aligned for best results.

\section{National Association for Gifted Children}

The NAGC $(2006,2010)$ is a professional organization focused on advocacy, education, and understanding of children who display gifted potential or outstanding talent (G/T). In 1998, the organization offered its first set of program standards. Over time, NAGC has developed different sets of standards for teacher preparation, standards for general education teachers, advanced standards for teacher preparation, and programming standards for providing services for students identified as gifted. It is the programming and teacher preparation standards that were used in this research as they are the most relevant to what happens on a day-to-day basis in G/T classrooms for children who are gifted. The 2010 revision for the programming standards, which was the most recently adopted standards when this research occurred, matches G/T program standards with teacher education standards, and is designed to provide high quality student outcomes through the use of research-based practice (National Association for Gifted Children, 2010). Links to these standards are available at http://www.nagc.org/resources-publications/resourcesuniversity-professionals .

Although the evidence-based practices are fairly prescriptive with respect to teaching strategies and skills, the student outcomes are aptitudes that intersect with the ISTE NETS indicators and the P21 Framework for $21^{\text {st }}$ Century Learning (International Society for Technology in Education, 2010; National Association for Gifted Children, 2010; Partnership for 21st Century Skills, 2004). Learner outcomes are discussed in terms such as, providing opportunities for students who are gifted to learn content related to their interest, use instructional strategies that promote creativity, critical-thinking, and problem-solving and the use of communication tools such as assistive technologies. Many of the NAGC standards relate to providing resources for learning, but also for enrichment and connection with mentors or community resources and for assessment. Technology is one possible tool for making these connection and resources possible. 


\section{Overlap of Standards and the P21 Framework}

There exists significant overlap between the content of the ISTE standards and that of the NAGC standards (International Society for Technology in Education, 2010; National Association for Gifted Children, 2010); however, both of these sets of standards are contained entirely within the P21 Framework (International Society for Technology in Education, 2010; National Association for Gifted Children, 2010; Partnership for 21st Century Skills, 2004). Figure 1 visually represents the overlap between the three sets of standards.

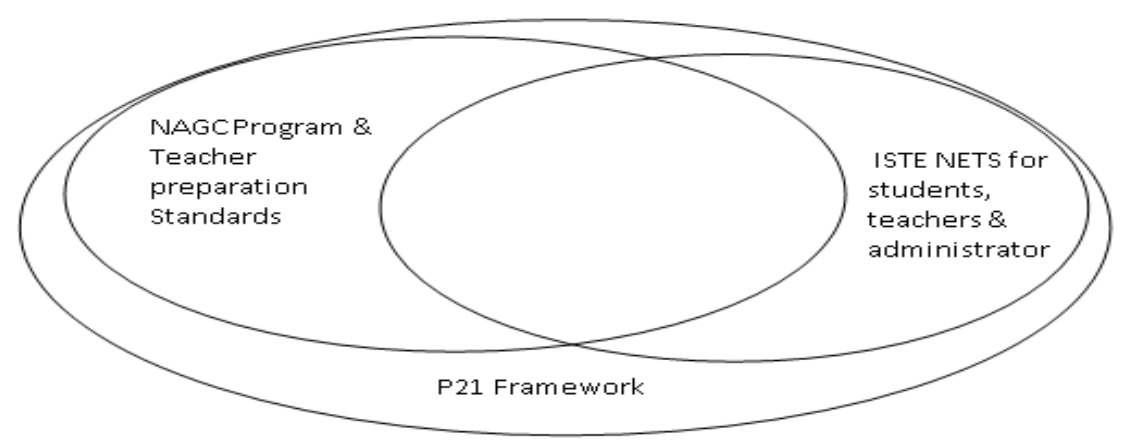

Figure 1: Visual of the overlap between standards from three organizations

\section{Research Question}

A technology-rich classroom will be defined as a classroom where a teacher regularly, purposefully, and meaningfully uses technology with students to enhance learning (Elstad, 2008). The term technology-rich is therefore more dependent on the ways that the teacher uses technology and less dependent on the quantities and types of technology available. The research focus of this study was:

- In what ways do teachers' uses of technology with G/T students shape students' technology experiences?

\section{Methodology}

There often are many different ways a specific technology can be used and it is hard to account for all of the possible uses through a closed survey (Bebell et al., 2004; Bebell et al., 2010; Clarke-Midura \& Dede, 2010; Hall, 2010). General research may not account for the purpose of the technology use (Lagrange \& Erdogan, 2009). A yes and no survey, or even use of a Likerttype scale indicating frequency of use, cannot measure the quality of implementation of educational technology (Hall, 2010). Other research methods are necessary.

The overarching goal of this study was to provide a thick description and understanding from the perspective of the teacher of how teachers of G/T students incorporate technology in the classroom. The researcher sought to analyze and document the individual experience of G/T teachers using technology in their classrooms. A qualitative phenomenological multi-case study approach was used (Creswell, 2007; Smith \& Osborn, 2004) because the descriptions and explanations made about teachers' technology use with students (Merriam, 1988; Smith \& Osborn, 2004) were based on the teachers' perceptions. The emphasis was on meaning making and examining the process rather than on a final outcome (Merriam, 1988). This research was not designed to manipulate or control the situation, but to describe and interpret classroom practice (Smith \& Osborn, 2004). 


\section{Participants}

In phenomenological case studies participant selection is deliberate so that the people are interesting and practical representations of the population being studied (Smith \& Osborn, 2004). All of the participants were teachers who had obtained G/T education certification through the master's level certification program at The University of Alabama. Participants were found by using an extant database of program graduates who had completed a survey on how important the teachers believed the $21^{\text {st }}$ Century Skills were for their students, and how effective they felt they were in teaching those skills. Results from the survey were culled to find teachers who both used technology frequently and shared similar attitudes and beliefs to identify a homogenized sample (Smith \& Osborn, 2004). A total of six teachers were found to participate in the study. The demographics of the participating teachers and the schools where observations took place are summarized in Table 1 .

\begin{tabular}{|l|l|l|l|l|l|}
\hline \multicolumn{5}{|c|}{ Table 1: Description of participants and their schools } \\
\hline $\begin{array}{l}\text { Partic- } \\
\text { ipant }\end{array}$ & $\begin{array}{l}\text { Years } \\
\text { teach- } \\
\text { ing G/T }\end{array}$ & $\begin{array}{l}\text { School } \\
\text { location }\end{array}$ & Title I designation & $\begin{array}{l}\text { School } \\
\text { Size }\end{array}$ & Sample technologies available \\
\hline Abby & 6 & $\begin{array}{l}\text { Subur- } \\
\text { ban }\end{array}$ & $\begin{array}{l}\text { No, 0\% of students } \\
\text { receive free or reduced } \\
\text { lunch }\end{array}$ & $\begin{array}{l}>500 \text { stu- } \\
\text { dents } \\
\text { K-6 }\end{array}$ & $\begin{array}{l}\text { Laptop cart, broadcast room and } \\
\text { equipment, 2 iPads, 4 Lego Robot- } \\
\text { ics kits, SMART Board }\end{array}$ \\
\hline Bati & 6 & $\begin{array}{l}\text { Subur- } \\
\text { ban }\end{array}$ & $\begin{array}{l}\text { Yes, 33\% of students } \\
\text { receive free or reduced } \\
\text { lunch }\end{array}$ & $\begin{array}{l}>600 \text { stu- } \\
\text { dents K- } \\
5^{\text {th }}\end{array}$ & $\begin{array}{l}\text { Several desktop computers, Net- } \\
\text { books for checkout, classroom pro- } \\
\text { jector }\end{array}$ \\
\hline Emilia & 11 & Rural & $\begin{array}{l}\text { Yes, 50\% of students } \\
\text { receive free or reduced } \\
\text { lunch }\end{array}$ & $\begin{array}{l}>1,100 \\
\text { students } \\
\text { preK-5 }\end{array}$ & $\begin{array}{l}\text { SMART Board, several desktop } \\
\text { computers, Netbooks for checkout, } \\
\text { Eggspert response system }\end{array}$ \\
\hline Kayla & 7 & $\begin{array}{l}\text { Subur- } \\
\text { ban }\end{array}$ & $\begin{array}{l}\text { No, 25\% of students } \\
\text { receive free or reduced } \\
\text { lunch }\end{array}$ & $\begin{array}{l}>1,300 \\
\text { students } \\
\text { K-6 }\end{array}$ & $\begin{array}{l}\text { Classroom projector, some newer } \\
\text { desktop computers, some older } \\
\text { desktop computers, digital cameras }\end{array}$ \\
\hline Lettie & 4 & $\begin{array}{l}\text { Rural } \\
\text { fringe }\end{array}$ & $\begin{array}{l}\text { Yes, 62\% of students } \\
\text { receive free or reduced } \\
\text { lunch }\end{array}$ & $\begin{array}{l}>200 \text { stu- } \\
\text { dents } \\
\text { preK-5 }\end{array}$ & $\begin{array}{l}\text { A couple desktop computers, } \\
\text { SMART Board, classroom projec- } \\
\text { tor system, Interwrite Modi tablet, } \\
\text { graphing calculators }\end{array}$ \\
\hline Willa & 10 & $\begin{array}{l}\text { Rural } \\
\text { fringe }\end{array}$ & $\begin{array}{l}\text { No, 37\% of students } \\
\text { receive free of reduced } \\
\text { lunch }\end{array}$ & $\begin{array}{l}>330 \text { stu- } \\
\text { dents K- } \\
5^{\text {th }}\end{array}$ & $\begin{array}{l}\text { Laptops for checkout, some older } \\
\text { desktop computers, classroom pro- } \\
\text { jector }\end{array}$ \\
\hline
\end{tabular}

\section{Data Sources}

Data collection began in June and continued until December of 2011. Three sources of data were analyzed and triangulated: a lesson plan, an interview, and two observations per participant. Table 2 summarizes the data sources, the anticipated codes from each source and the basis for anticipating those codes.

For the interview, a protocol of suggested questions and possible follow-up questions was used. The list of questions was developed by the researcher based on the body of literature (Smith \& Osborn, 2004) concerning technology in education. In particular, the questions were developed with ISTE (2010), NETS, and the P21 Framework (2004) in mind. 
Table 2: Summary of data plan

\begin{tabular}{|c|c|c|}
\hline Data Source & Anticipated Codes & Supporting Citations \\
\hline $\begin{array}{l}\text { Lesson Plan } \\
\text { (Creswell, 2007; J. A. } \\
\text { Smith \& Osborn, 2004) }\end{array}$ & $\begin{array}{l}\text { Various resources, student engagement and re- } \\
\text { flection, accuracy, purpose, connection to big } \\
\text { ideas, students' lives, student-directed versus } \\
\text { teacher-directed }\end{array}$ & $\begin{array}{l}\text { (Martin et al., 2010; } \\
\text { Peterson \& Bond, 2004; } \\
\text { Siegel, 2005; Zembal-Saul } \\
\text { et al., 2002) }\end{array}$ \\
\hline $\begin{array}{l}\text { Interview } \\
\text { (Creswell, 2007; ISTE } \\
\text { 2010, P21 2004; J. A. } \\
\text { Smith \& Osborn, 2004) }\end{array}$ & $\begin{array}{l}\text { Instruction versus assessment, technical support } \\
\text { to students, available technology, personal atti- } \\
\text { tude, teaching philosophy, technical support }\end{array}$ & $\begin{array}{l}\text { (Peterson \& Bond, 2004; } \\
\text { Zembal-Saul et al., 2002) }\end{array}$ \\
\hline $\begin{array}{l}\text { Observation } \\
\text { (Creswell, 2007) }\end{array}$ & $\begin{array}{l}\text { Degree of innovation, variety of resources, stu- } \\
\text { dent engagement, connection to big ideas, con- } \\
\text { nections to students' lives, student-directed ver- } \\
\text { sus teacher-directed, student reflection }\end{array}$ & $\begin{array}{l}\text { (Peterson \& Bond, 2004; } \\
\text { Zembal-Saul et al., 2002) }\end{array}$ \\
\hline
\end{tabular}

Questions about student-centered teaching related to technology practices, as well as questions concerning attitudes toward technology, were intended to provide insight into understanding the issue being studied (Creswell, 2007). The protocol guided, but did not dictate, the interview (Smith \& Osborn, 2004). The interviews were recorded and transcribed for coding purposes (Creswell, 2007; Smith \& Osborn, 2004).

During the observations, the researcher took field notes, both using an observation protocol and descriptive note-taking (Marshall \& Rossman, 2011). The observation protocol sheet was based on the Framework for $21^{\text {st }}$ Century Learning and was designed by the researcher.

\section{Data Analysis}

As is traditional with qualitative research data, the texts of the lesson plans, interview transcripts, and field notes were analyzed for themes. An iterative process was used to examine for both explicit and implicit codes until all participants' lesson plans had been read for all of the codes that emerged. Then the process was repeated for the interview transcripts, and followed by the same process for the observation field notes. Reanalyzing data ensured that if a theme was present only a small number of times in one participant's data that it was not missed during initial coding. This analysis and reanalysis process continued until a cohesive body of codes had been discovered (Creswell, 2007; Smith \& Osborn, 2004). Multiple reviews of the data were necessary.

An emerging research design was used. Data analysis co-occurred with data collection. Analysis influenced collection and vice versa. As units of data were segmented, they were collected, organized and manipulated using a computer spreadsheet (Creswell, 2007). Thematic coding was both within-case and cross-case in nature, and themes emerged from similarities or differences among teaching contexts (Siegle, 2005) and characteristics of participants (Creswell, 2007; Smith \& Osborn, 2004). Additionally, cross-case analysis helped yield an understanding of how differences in teachers' conceptions of what instructional technology means and how it should be implemented influenced their use of it (Siegle, 2005).

Reflection on the data was important in developing an understanding of instructional technology use. The researcher anticipated and created codes, related categories, kept code frequency counts, found illustrative cases (Siegle, 2004), and developed generalizations as ways of promoting reflection about the data. These forms of reflection were aided by the manipulation of data available through the use of spreadsheet software. The researcher kept a record of ideas, interpretations, themes, and decisions that emerged throughout the study (Creswell, 2007). 
Both direct interpretation and categorical aggregation of codes were possible with these data sources. The emphasis was on creating a rich description and not on generating generalizability of the findings; however, patterns and naturalistic generalizations emerged from the data (Creswell, 2007; Smith \& Osborn, 2004).

\section{Member Checking and Triangulation}

Once data collection was completed, participants verified the accuracy of the data. They gave confirmation of the logic and sufficiency of the coding and analysis through member checking for accuracy of themes. This was done via email.

Triangulation of the lesson plans, interviews, and observation field notes provided corroborating evidence of the participant's perspectives (Creswell, 2007). The data from the three sources provided a more complete picture of technology use in $\mathrm{G} / \mathrm{T}$ classrooms, as well as themes from one data source verifying themes from another source. Coding for themes developed as the study progressed. Detailed field notes and a record of coding and data decisions increased the reliability of the study (Creswell, 2007).

Anticipated areas of interest were the curriculum in which lessons used technology, the degree of autonomy given to students during lessons, whether differentiation was present, and how technology was used to create the differentiation when it was present. Particular attention was paid to themes from the $21^{\text {st }}$ century skills framework such as creativity, communication, collaboration, life and career skills, and digital literacy (Partnership for 21st Century Skills, 2004). Additional significant themes emerged as data were collected and analyzed.

The levels of analysis ranged from classification and typology to an examination of the complexity and difficulties of using technology in the classroom. Finally, interpretations and assertions were made (Creswell, 2007; Smith \& Osborn, 2004) concerning the levels of autonomy and differentiation teachers provided to students through technology, and whether $21^{\text {st }}$ century skills drive technology use in lessons.

\section{Limitations and Delimitations}

A limitation of this research was that the researcher may have some bias toward the outcomes, due to her background in G/T education and her own interest in technology and how it can be used with students. The researcher cannot fully separate herself from her perspectives, which influenced data collection and analysis.

Not every educator who earns a certification in G/T education teaches in this environment. Some $\mathrm{G} / \mathrm{T}$ certified teachers work in various administrative positions or in general education classrooms. A delimiting factor for participant selection was that the participant teaches in a position with a title related to being a specialist in G/T education. Required teaching objectives for teachers of general education versus teachers of the $\mathrm{G} / \mathrm{T}$ are different. In Alabama at the time of this research, G/T education at the elementary school level was delivered primarily through enrichment content determined by individual school districts or even individual G/T teachers. Teachers in $\mathrm{G} / \mathrm{T}$ education environments had greater freedom in the content they taught than teachers of general education. Differences in teachers' levels of control over the curriculum were a limitation in the study, as they may influence what was being taught.

It was assumed that all participants were open and honest, and that participants did not alter their opinions and perspectives to please the researcher. By choosing teachers who reported frequent technology use, it is assumed that their perspectives on teaching differed from other teachers who infrequently use technology with students. 
Finally, the initial selection of participants was based on extant survey data for program evaluation. That all of the participants are alumni of the same program influenced the data. The descriptions obtained in this phenomenological multi-case study may not be typical for all teachers, due to the small sample size and the potential uniformity in characteristics of the participants. However, transferability of findings to particular situations that have similarities to the participants in this study may be possible.

\section{Results}

The lesson plans yielded 87 data segments, the interviews produced 669, and the observations contained 261. The data from the three data sources were each determined to have between one and five different code names identifying the central concepts found within each segment. Some of the concepts were explicit, but for some, careful reflection was required to tease out the implicit ideas. A reflective journal was kept as codes were labeled and themes emerged. The codes were sorted and arranged to create four categories of relationships between and among the themes: characteristics related to the teacher; issues related to the technology equipment; topics concerning pedagogical features; and factors regarding students. The themes are explained in this section through delineating which codes were grouped to form each theme. Additionally, the codes are further explained through definitions and examples to help the reader understand why each label was used and how it contributes to understanding the major themes.

\section{Codes and Themes}

\section{About the Teacher}

During data collection and analysis, commonalities among all participant teachers were found, including shared teaching philosophies, attitudes towards technology, and classroom climates created by the teachers. Characteristics of the G/T teachers that shaped students' interactions with technology included the climate of the G/T classroom, the bonding between the teacher and the students, general attitudes of the teacher, and teacher expertise with technology. Table 3 provides definitions and examples that emerged as commonalities among the $\mathrm{G} / \mathrm{T}$ teacher participants.

\begin{tabular}{|c|c|c|}
\hline \multicolumn{3}{|c|}{ Table 3: About the teacher } \\
\hline Code & Definition & Examples \\
\hline Climate & $\begin{array}{l}\text { Classroom's physical } \\
\text { layout and atmosphere }\end{array}$ & $\begin{array}{l}\text { Computers arranged for simultaneously helping multiple stu- } \\
\text { dents, relaxed atmosphere, student have some autonomy }\end{array}$ \\
\hline Bonding & $\begin{array}{l}\text { A high level of trust and } \\
\text { knowledge by the teacher } \\
\text { towards the students }\end{array}$ & $\begin{array}{l}\text { Teachers trust their students, students provide technical support } \\
\text { to teacher, Teachers know students' abilities, interests, and } \\
\text { motivations, Long term relationship over more than one year }\end{array}$ \\
\hline Attitude & $\begin{array}{l}\text { Similar dispositions be- } \\
\text { tween the participant } \\
\text { teachers }\end{array}$ & $\begin{array}{l}\text { Personal mission in teaching (e.g., environmental education, } \\
\text { cultural awareness), curiosity, seeking learning opportunities, } \\
\text { work with technology experts, trying new technology }\end{array}$ \\
\hline Opportunity & Learning from experience & $\begin{array}{l}\text { Past technology issues inform future practice, in future lessons } \\
\text { predicting and planning to prevent potential problems }\end{array}$ \\
\hline Expertise & $\begin{array}{l}\text { Fluency with using or } \\
\text { teaching with technology }\end{array}$ & $\begin{array}{l}\text { Use technology personally and professionally, use technology } \\
\text { with students, help others with technology, identify potential } \\
\text { issues using technology with students }\end{array}$ \\
\hline Influence & $\begin{array}{l}\text { Motivation to use certain } \\
\text { technologies or strategies } \\
\text { that use technology }\end{array}$ & $\begin{array}{l}\text { Conferences and professional development motivate trying } \\
\text { technologies, mentoring other teachers in technologies, seeing } \\
\text { how technology from personal lives could be in classrooms, } \\
\text { motivated to use technology to make job easier }\end{array}$ \\
\hline
\end{tabular}




\section{Equipment}

Equipment could mean both the hardware and software used in the G/T classrooms. The equipment available for teachers and students to use influenced the activities they were able to do. The definitions and examples in Table 4 explain the concepts that frame the theme of equipment and its influence on how the G/T teachers used educational technology.

\begin{tabular}{|l|l|l|}
\hline \multicolumn{3}{|c|}{ Table 4: Equipment } \\
\hline Code & Definition & Examples \\
\hline $\begin{array}{l}\text { Funding: } \\
\text { Constraints }\end{array}$ & $\begin{array}{l}\text { District or school level financial } \\
\text { decisions determined what was } \\
\text { available to the teachers, both in } \\
\text { equipment and time }\end{array}$ & $\begin{array}{l}\text { Working with available technology (equipment, soft- } \\
\text { ware, and available websites), limited funding create } \\
\text { gaps in support available limiting exploration, limited } \\
\text { time with students }\end{array}$ \\
\hline $\begin{array}{l}\text { Funding: } \\
\text { Assets }\end{array}$ & $\begin{array}{l}\text { What equipment was available } \\
\text { determined what the teachers do } \\
\text { and do not have }\end{array}$ & $\begin{array}{l}\text { Available equipment fully utilized, desired additional } \\
\text { equipment, sought funding for desired equipment }\end{array}$ \\
\hline $\begin{array}{l}\text { Assets: } \\
\text { Timeliness }\end{array}$ & $\begin{array}{l}\text { How up-to-date the equipment, } \\
\text { both software and hardware is } \\
\text { believed to be by the teachers and } \\
\text { the students }\end{array}$ & $\begin{array}{l}\text { Old equipment with limited capabilities caused frustra- } \\
\text { tion and desire for new equipment, newer equipment } \\
\text { has multiple functions (e.g., tablets play music and surf } \\
\text { the Internet) }\end{array}$ \\
\hline $\begin{array}{l}\text { Assets: } \\
\text { Partitioning }\end{array}$ & $\begin{array}{l}\text { Distribution of technology at the } \\
\text { school }\end{array}$ & $\begin{array}{l}\text { Equipment in the G/T classroom available if it worked, } \\
\text { school-wide equipment for check out depended on oth- } \\
\text { er's rate of use, scheduled equipment unevenly availa- } \\
\text { ble during times for different groups of G/T students }\end{array}$ \\
\hline
\end{tabular}

\section{Pedagogy}

Pedagogy encompasses the decisions that teachers made that influenced students experience with technology. These decisions included both planned and spontaneous lesson features including issues such as whether there was flexibility in the lessons so that students had some autonomy, where scaffolding was present, presence of mini-lessons, subject matter with which the technology was integrated, the sequencing of instructional activities, and the hands-on practice time planned for students. The theme of pedagogy is described in Tables 5A, 5B and 5C so that each subsection of the theme could be sufficiently described.

\begin{tabular}{|l|l|l|}
\hline \multicolumn{3}{|c|}{ Table 5A: Pedagogy: Learning activities with technology } \\
\hline Code & Definition & Examples \\
\hline Pacing & $\begin{array}{l}\text { Control of the } \\
\text { time spent on } \\
\text { learning tasks } \\
\text { in a lesson }\end{array}$ & $\begin{array}{l}\text { Teachers planned play time with equipment, minimal direct instruction, } \\
\text { more time for students to explore and figure it out on their own, limited } \\
\text { time and complex tasks caused chunking over multiple lessons, pacing con- } \\
\text { trolled verbally, through worksheets, and through collaboration, equipment } \\
\text { prepped for students }\end{array}$ \\
$\begin{array}{l}\text { Practice/ } \\
\text { Hands-on/ } \\
\text { Exploratory }\end{array}$ & $\begin{array}{l}\text { Students used } \\
\text { the technolo- } \\
\text { gy directly }\end{array}$ & $\begin{array}{l}\text { Students allowed to experiment with technology prior to learning tasks, } \\
\text { individual technology practice balanced with group work, experts provided } \\
\text { scaffolding to novices }\end{array}$ \\
\hline
\end{tabular}




\begin{tabular}{|l|l|l|}
\hline \multicolumn{3}{|c|}{ Table 5B: Pedagogy: Characteristics of teaching with technology } \\
\hline Code & Definition & Examples \\
\hline Mentoring & $\begin{array}{l}\text { Teachers helped students connect } \\
\text { with professionals }\end{array}$ & $\begin{array}{l}\text { Adults found across the country for online communi- } \\
\text { cate with students, experts found in various areas }\end{array}$ \\
\hline $\begin{array}{l}\text { Flexibility/ } \\
\text { Personali- } \\
\text { zation }\end{array}$ & $\begin{array}{l}\text { Students have some choice or au- } \\
\text { tonomy, sometimes in small facets } \\
\text { but at other times in larger aspects }\end{array}$ & $\begin{array}{l}\text { Technology lessons differentiated for skill levels; stu- } \\
\text { dents choice in topic, collaborative roles, products, or } \\
\text { features; mostly independent work, students located } \\
\text { additional resources as needed }\end{array}$ \\
\hline $\begin{array}{l}\text { On- } \\
\text { Demand }\end{array}$ & $\begin{array}{l}\text { Teachers taught lessons on skills as } \\
\text { students needed them }\end{array}$ & $\begin{array}{l}\text { Spontaneous individual or small group help lessons as } \\
\text { needed with skills needed immediately }\end{array}$ \\
\hline Scaffolding & $\begin{array}{l}\text { Teachers sequenced learning with } \\
\text { technology to support increasing } \\
\text { technology fluency and complexity }\end{array}$ & $\begin{array}{l}\text { Anticipation of readiness based on knowledge of the } \\
\text { students, sequencing of technology skills planned } \\
\text { across years spent with students, technology skills not } \\
\text { embedded in content taught skills for another lesson }\end{array}$ \\
\hline
\end{tabular}

\begin{tabular}{|l|l|l|}
\hline \multicolumn{3}{|c|}{ Table 5C: Pedagogy: Content of teaching with technology } \\
\hline Code & Definition & Examples \\
\hline Integration & $\begin{array}{l}\text { The degree to which learning to } \\
\text { use technology was embedded in } \\
\text { learning content }\end{array}$ & $\begin{array}{l}\text { Technology embedded in content, technology skills } \\
\text { taught separately required direct instruction and were } \\
\text { used later, content selected before equipment }\end{array}$ \\
\hline Planning & $\begin{array}{l}\text { Decisions teachers made to organ- } \\
\text { ize learning activities using tech- } \\
\text { nology }\end{array}$ & $\begin{array}{l}\text { Frequently technology matched to products or topic, } \\
\text { rarely was technology selected first, lesson pattern one } \\
\text { was to model new technology and then students } \\
\text { worked independently, lesson pattern two was imita- } \\
\text { tion of the teacher mid-lesson to address problems not } \\
\text { easily solved by students, lesson pattern three was } \\
\text { verbal instructions and fluent students got to work }\end{array}$ \\
\hline Complexity & $\begin{array}{l}\text { Where learning tasks were on a } \\
\text { continuum from explicit to vague }\end{array}$ & $\begin{array}{l}\text { Fluency developed faster with complex tasks than } \\
\text { tutorials, constructivist lessons preferred for students } \\
\text { to learn technology }\end{array}$ \\
\hline $\begin{array}{l}\text { Critical } \\
\text { Thinking }\end{array}$ & $\begin{array}{l}\text { Learning tasks with higher order } \\
\text { thinking (e.g., problem solving, } \\
\text { creativity, analysis, evaluation) }\end{array}$ & $\begin{array}{l}\text { Most times technology was a tool, critical thinking } \\
\text { occurred in content instruction, technology tasks de- } \\
\text { veloped creativity }\end{array}$ \\
\hline
\end{tabular}

\section{About the Students}

The theme that appeared to have the greatest influence on what the G/T teachers did with their students was issues related to the students. The first grouping of student codes included information about the students themselves: background or family life of the students, characteristic behaviors of the students, and the development of authentic learning activities for the students. The second grouping of codes included goals that teachers had for students: building life-long dispositions, general cognitive dispositions, specific thinking skills, practice with collaboration, development of reflection, and an understanding of the role of the author. The final grouping of student codes related to technology use, such as the development of technology-literacy and support for using technology. This theme is defined and described by the information in Tables $6 \mathrm{~A}$, $6 \mathrm{~B}$, and $6 \mathrm{C}$. 


\begin{tabular}{|l|l|l|}
\hline \multicolumn{3}{|c|}{ Table 6A: About the students: Technology experiences } \\
\hline Code & Definition & Examples \\
\hline Support & $\begin{array}{l}\text { How much and what kind of } \\
\text { assistance teachers gave students } \\
\text { using technology }\end{array}$ & $\begin{array}{l}\text { Knowing when to allow struggle versus help, varied speci- } \\
\text { ficity of instructions for technology projects, helped devel- } \\
\text { op district technology standards }\end{array}$ \\
\hline Process & Learning how to use technology & $\begin{array}{l}\text { Tech-fluency scaffolded, exposure to technology complexi- } \\
\text { ty even if mastery not expected, moved towards students } \\
\text { understanding technology accurately }\end{array}$ \\
\hline $\begin{array}{l}\text { Tech- } \\
\text { literacy }\end{array}$ & $\begin{array}{l}\text { The fluency with which the stu- } \\
\text { dents can use technology }\end{array}$ & $\begin{array}{l}\text { Tech-literacy partially related to grade level, planned differ- } \\
\text { entiation of technology, skilled students allowed extra re- } \\
\text { sponsibilities, progression of tech-fluency understood }\end{array}$ \\
\hline $\begin{array}{l}\text { Respon- } \\
\text { sibility }\end{array}$ & $\begin{array}{l}\text { Teaching students to use tech- } \\
\text { nology safely and in mature } \\
\text { ways }\end{array}$ & $\begin{array}{l}\text { Teaching Internet safety, questioning reliability of online } \\
\text { sources, responsible use at home versus school, plagiarism, } \\
\text { modeling or coaching before students work independently } \\
\text { (e.g., private blogging before class blogging) }\end{array}$ \\
\hline $\begin{array}{l}\text { Preven- } \\
\text { tion }\end{array}$ & $\begin{array}{l}\text { Working to help keep problems } \\
\text { from occurring in the first place }\end{array}$ & $\begin{array}{l}\text { Teaching trouble-shooting, brain-storming for different sce- } \\
\text { narios, peer help before teacher help, encouraging inde- } \\
\text { pendence with technology, anticipating problems and pre- } \\
\text { ventative planning, student created tutorials }\end{array}$ \\
\hline $\begin{array}{l}\text { Purpose/ } \\
\text { Accura- } \\
\text { cy }\end{array}$ & $\begin{array}{l}\text { Development of student under- } \\
\text { standing of what different tech- } \\
\text { nologies can and cannot do }\end{array}$ & $\begin{array}{l}\text { Technology as a resource or tool, specific uses for certain } \\
\text { programs or equipment, clarification for accuracy of tech- } \\
\text { nology knowledge, examples of real world technology use }\end{array}$ \\
\hline
\end{tabular}

\begin{tabular}{|l|l|l|}
\hline \multicolumn{3}{|c|}{ Table 6B: About the students: Student contexts } \\
\hline Code & Definition & Examples \\
\hline Authenticity & $\begin{array}{l}\text { Learning activities with tech- } \\
\text { nology that are real word au- } \\
\text { thentic activities }\end{array}$ & $\begin{array}{l}\text { Technology like adults use (e.g., social media, online } \\
\text { mortgage calculators), peer-editing, peer-teaching of con- } \\
\text { tent or skills }\end{array}$ \\
\hline Engagement & $\begin{array}{l}\text { The degree of active attention } \\
\text { or involvement a student has } \\
\text { in a lesson }\end{array}$ & $\begin{array}{l}\text { Quieter students more active in online forums, frequent } \\
\text { online access of school content at home, teacher belief of } \\
\text { more active engagement with laptops than whole group } \\
\text { instruction, technology use sometimes distracting }\end{array}$ \\
\hline $\begin{array}{l}\text { Characteris- } \\
\text { tics }\end{array}$ & $\begin{array}{l}\text { Student attributes that influ- } \\
\text { enced teachers' decisions } \\
\text { about when and how to use } \\
\text { technology with students }\end{array}$ & $\begin{array}{l}\text { Some student easily gain tech-fluency while others need } \\
\text { more support and practice, most G/T students motivated } \\
\text { to explore technology and complex features, student be- } \\
\text { havior and maturity influence planned use of technology }\end{array}$ \\
\hline $\begin{array}{l}\text { Distribution } \\
\text { (Publishing) }\end{array}$ & $\begin{array}{l}\text { Projects had a wider audience } \\
\text { than just the teacher }\end{array}$ & $\begin{array}{l}\text { Students motivated by sharing via the Internet, project } \\
\text { fairs, contests, or school broadcasts }\end{array}$ \\
\hline Connection & $\begin{array}{l}\text { Connections to the students' } \\
\text { lives outside of school }\end{array}$ & $\begin{array}{l}\text { As student expertise increased products shared with wider } \\
\text { audiences, students allowed to explore interests outside of } \\
\text { school content }\end{array}$ \\
\hline Context & $\begin{array}{l}\text { The background experiences } \\
\text { that shape students' technolo- } \\
\text { gy experiences outside of } \\
\text { school }\end{array}$ & $\begin{array}{l}\text { Home technology continuum from only owning a TV to } \\
\text { all family members having tablets and cell phones, parent } \\
\text { technology continuum from permissive to restrictive, } \\
\text { parental fluency influences student support, technology } \\
\text { experiences influence fluency and perspective, students' } \\
\text { overall tech-literacy influences teaching, local schools' } \\
\text { purchases match technology levels in students' homes }\end{array}$ \\
\hline
\end{tabular}


Table 6C: About the students: Goals for students

\begin{tabular}{|l|l|l|}
\hline Code & Definition & Examples \\
\hline $\begin{array}{l}\text { Life (Dispo- } \\
\text { sitions) }\end{array}$ & $\begin{array}{l}\text { Development of characteristics that } \\
\text { positively impact students into } \\
\text { adulthood }\end{array}$ & $\begin{array}{l}\text { Technology believed important to future success, } \\
\text { technology activities develop skills (e.g., research, } \\
\text { persistence, communication), teachers model desired } \\
\text { attitudes }\end{array}$ \\
\hline $\begin{array}{l}\text { Collabora- } \\
\text { tion }\end{array}$ & $\begin{array}{l}\text { Development of social skills relat- } \\
\text { ed to working in a group }\end{array}$ & $\begin{array}{l}\text { Practice working in groups, group structured balanc- } \\
\text { es students' strengths and needs, students consult } \\
\text { each other in decisions, students assign roles and } \\
\text { tasks, students give technology support in their group }\end{array}$ \\
\hline $\begin{array}{l}\text { Expectations } \\
\text { Cognition }\end{array}$ & $\begin{array}{l}\text { Ways teachers developed students' } \\
\text { mental abilities }\end{array}$ & $\begin{array}{l}\text { Expectation of proper technology vocabulary, stu- } \\
\text { dents given rubrics and exemplar products }\end{array}$ \\
\hline Reflection & $\begin{array}{l}\text { Ways teachers developed students' } \\
\text { evaluation of their work or abilities }\end{array}$ & $\begin{array}{l}\text { Students did self-evaluations, debriefing at the end of } \\
\text { lessons, and evaluation of technology }\end{array}$ \\
\hline $\begin{array}{l}\text { Caliber/ } \\
\text { Quality }\end{array}$ & $\begin{array}{l}\text { Teachers expected student work to } \\
\text { be excellent }\end{array}$ & $\begin{array}{l}\text { "Go above and beyond,"Show me what you know } \\
\text { in a creative way," student work monitored for basic } \\
\text { skills mastery, G/T work "bumped up" compared to } \\
\text { general education classrooms }\end{array}$ \\
\hline
\end{tabular}

\section{Discussion}

Teachers shaped students' technology experiences through the equipment they used and the pedagogical decisions they made, in the context of characteristics of both the students and the teachers. Students experienced technology in ways that taught them that technology was to be explored, used independently, and integrated in all areas of life, even if it required persistence at times. Teachers highlighted technology's role in careers and the future; that it is a tool, available in a variety of forms that are constantly being updated. The teachers differentiated casual use of technology from more professional uses, by demanding that students produce quality work. The students were introduced to technology's potential use as a tool for creative productivity.

\section{Pedagogy}

The expertise that the teachers had gained was due to the frequency with which they taught with technology and consistently put technology into the hands of students. Experience gave the teachers insights into how to plan and sequence lessons that used technology. As Clausen (2007) found, experience helped the teachers in this study blend technology with their teaching rather than making it a separate component. From experience, the participants knew the activities the students needed to do before getting on the computer, such as completing research or organizing their ideas on paper.

The teachers understood that their G/T students needed some time to explore the technology and to figure it out on their own before being asked to use it in formal ways for whatever unit on which the class was working. Experience also helped the teachers know when they would have to be specific about steps and processes when doing a task with different pieces of equipment or special programs. Teachers had developed an understanding of when to let the students struggle a little bit and when to provide support so that students did not become frustrated, and they also used their knowledge of when students were likely to encounter problems to plan ahead to prevent the problems. All of the participants encouraged the students to draw on knowledge of how 
to use other technologies when learning about a new technology. In these classrooms, technology was approached with a sense of curiosity. The attitudes and approaches to technology with which the teacher planned student experiences were reflections of how each teacher approached technology herself.

The teachers promoted independence with the technology. For the most part, they wanted the students to work and have opportunities to work by themselves. Independence with technology is not a concept or skill that has been explored in previous studies. This attitude is in contrast to the P21 Framework (2004), which promotes development of collaboration skills in students. The data contained some examples of collaboration by students and students had some online access to either experts or other students with similar interests, but it was clear that independent technology use was the teachers' goal.

Students worked in pairs or small groups on occasion, but partnerships were just as likely to be due to having limited equipment or time as they were for the teacher to have purposefully partnered students. When the teacher did partner students, it was for one student to aid the other either in using the technology or in being a role model in exploring the technology. While teacher support was provided when necessary, students were encouraged to trouble-shoot and figure out technology's functions and features on their own. Thus, the participants placed more emphasis on independent work then on building skills in collaboration.

\section{Knowledge of Students}

Some of the factors influencing how teachers shaped students' experiences came from the students themselves. As found in previous research, differences in access to technology in students' home life influenced what teachers planned and were able to do with the stuents during school time (Ba et al., 2002; Siegle, 2004). The teachers gradually built up students' technology-literacy; often over the several years of contact between the G/T teachers and their students. Primarily, the teachers modeled and planned experiences with technology that promoted technology as a tool and a resource. Teachers scheduled times for sharing student work through technology. Technology was integrated, sometimes in complex ways, with a variety of subjects so that students were frequently simultaneously learning content and how to use technology. The teachers used technology themselves in ways that promoted technology not as something extra, but as equipment with a purpose to be used in multiple ways in all domains. Furthermore, technology was promoted as a tool that required responsible use.

One finding of this research not explored in previous studies was the level of trust and bonding between the G/T teachers and their students and how that relationship impacted the technology experience. In general, trust is a factor that affects what teachers are able to do with their students. It influences students' levels of cooperation, feelings of safety, and engagement in a classroom (Gregory \& Ripski, 2008; Penhasi-Vittorio \& Ben-Yosef, 2014). There was a high level of bonding demonstrated in the flexibility and freedom that the G/T teachers allowed their students, and this influenced the types of technology activities that the G/T teachers planned with their students.

Smaller class sizes and inclusion of multiple opportunities for students to directly use a variety of technology helped students develop technology-literacy. Because the G/T teachers worked with students over multiple years, they were able to sequence students' technology experiences so that the students' skills developed to higher levels than if the students had different teachers each year. Constrained by the limited amount of time each teacher saw her students during an individual week, they focused on helping the students learn how to manage goals and pacing towards completing projects. Technology was promoted as a worthwhile tool, not always easy to use, but one that with persistence as issues were solved could be mastered. Students were encouraged to work 
independently, and were given some limited opportunities to practice directing their own learning.

Classroom experiences with technology developed the skills listed in the P21 Framework (2004). The P21 Framework includes life and career skills, as well as information, media, and technology skills. The teachers, taking a long-term view, insisted that the students have enough hands-on experiences with technology that they develop skills for future careers. The students' technology literacy skills and the development of life and career skills benefited from the level of teacherstudent bonding that occurred in the G/T classrooms. Teachers asked students to reflect not only about the content they were learning, but also about their use of technology. These learning activities all support the P21 Framework Life and Career Skills outcomes.

\section{Professionalism}

Some factors that influenced educational technology use were not due to conscious decisions made by the teachers, but rather from the conditions of their particular teaching circumstances. As found in other studies, decisions made by the school district and by school administration influenced what the teachers in this study did with students (Clausen, 2007; Donovan et al., 2007; Wade, Rasmussen, \& Fox-Turnbull, 2013). As Chai, Koh, and Tsai (2013) found, limited technology resources or bureaucracy in acquiring access to the technology discourages teachers from using technology with students. The teacher participants did not always have access to the most recent and fastest equipment and there were often equipment and features the teachers would have liked to use but did not have.

The distribution of equipment at each school impacted how much individual hands-on experience and practice the teachers could plan with students. Some of the policies and practices of the schools and school districts, such as what websites were blocked and access to a computer labs or laptop carts, narrowed what the teachers were able to do. Sometimes the available equipment dictated how students were able to accomplish tasks. However, the teachers worked as much as they could around the limitations of equipment and access and presented technology to the students as a tool to be used for learning and creative productivity in a multitude of ways.

The attitudes of the participants, as evidenced in their interviews, was that they liked to play with technology and explore new tools, and it seems that this desire to seek out new technology translated into what the teachers wanted to do with their students. There were activities that the teachers mentioned, such as using QR code apps, that they would have liked to have had in their classrooms, but did not. Several of the participants were actively seeking grant money to update technology equipment. The impact on their teaching was that the teachers had to use the technology and the functionality of that technology that was available to them.

Students are bound to encounter problems when they are working hands-on with technology. As found in other research, the teachers in this study were more likely to use technology when they were comfortable using it (Fleming, Motamedi, \& May, 2007; Garcia \& Rose, 2007; Shaunessy, 2007; Taylor \& Duran, 2006). Other researchers have found that support using educational technology is important for teachers who are technology novices (Clausen, 2007); however, this research suggests that technology support is just as important for teachers experienced in using technology. The participants may have been experts in using some forms of technology, but as these teachers encountered new equipment, new programs, new uses, or new set-ups they sought out the help of technology experts.

As other researchers have found, long term exposure to technology, both within the classroom and in their personal lives, influenced teachers' technology use with students (Clausen, 2007; Fleming et al., 2007; Garcia \& Rose, 2007; Myles et al., 2007; Shaunessy, 2007; Taylor \& Duran, 2006). These teachers actively sought out training to help them plan how to better incorporate 
technology in their classrooms. Such training has been shown to influence teachers' use of educational technology (Clausen, 2007; Donovan et al., 2007; Fleming et al., 2007; Garcia \& Rose, 2007; Koehler \& Mishra, 2005). Just as Garcia and Rose (2007) found that preservice teachers imagined how they would use technology in their classrooms, the participants in this study, when exposed to a new technology, envisioned the ways in which they would encorporate it in their own teaching.

Some researchers suggest that teachers need increased time for colloboration with other teachers to work on ways to integrate technology in their classrooms (Clausen, 2007; Donovan et al., 2007). However, this research suggests that at least some teachers are currently using technology such as email or professional social networks to collaborate with other teachers who are interested in building their skills with educational technology. In this way, the teachers were not limited to access to teachers within their school building. The professional learning circle for the participants was increased due to the use of technology.

\section{Practical Implications}

The implications of this research are that if school and district administrators want teachers to actively use technology with students in meaningful ways, there are strategies that can be used to encourage it. Most obviously, the administration controls the technology available to teachers; however, this research indicates it is not so much the quantity of available technology, but the quality of its use that distinguishes teachers known for using educational technology with students from teachers who are not known for using technology with students.

\section{Pedagogy}

The most frequently occurring codes across the entire data set were about assets and supports. These are two areas where teachers typically have little control, as assets and expert support are primarily determined by decisions made at either the school administration level or at the school district level. In addition to making purchasing decisions about new equipment, administrations can examine whether there is a fair distribution of current equipment. Lack of access to a computer lab narrowed what the teachers were able to do. Schools can examine whether all teachers have equal access to the equipment, and should examine what types of activities are occurring with the equipment.

Some of the policies and practices of the schools and school districts, such as what websites were blocked, influence what teachers are able to do with students. School districts need to have a plan for making changes in access to online resources as educational uses are developed for those resources. For instance, some districts do not allow teachers to access social media sites, but one participant worked in a school district where Edmodo was used to provide technical support during class hours and between schools. Additionally, having a teacher panel to help evaluate the educational value of various Internet resources will help produce thoughtful decisions about what websites to block.

When school districts block websites without considering the educational potential of some websites, then it can impact more than the school day. Some participants in this study used blogs, wikis, and other applications accessible from homes to extend learning for the students. Students learned how to logon and use the blogs and wikis at school, but then also posted and worked from home on the same websites. At one school, students who did not have computer access at home were allowed to come to school early to be able to complete online work. Additionally, one teacher used a class wiki to communicate with parents. She worked on the wiki while she was at school, something she would not have been able to do if the school district had blocked the site. 
There is a difference between using technology to teach versus allowing the students to learn through technology. Part of the expertise of the teachers who participated in this study was due to the frequency with which they put technology into the hands of students. A teacher, who knows the specific direction and purpose of a lesson and who is already familiar with the content, presenting material using a SMART Board or a PowerPoint presentation takes less lesson time then allowing students to experience using technology in authentic ways. Students may require time to draft, time to determine essential understandings of the content, and time to conduct trial-anderror testing with the technology.

Technology projects should be integrated with other content. When students use technology teachers have to allow instructional time for students to explore and experiment with the technology, as the participants in this study did. Then, when administrators evaluate teachers about their technology use, the administrators can look for long-term projects and authentic projects that use technology over several days. Quality technology use is not always visible in a 45 minute single observation.

\section{Knowledge of the Learner}

As found in this study, the students themselves helped shape what kinds of technology use occurred. The participants in this study had the advantage of having their same group over students over multiple years. This allowed the teachers to plan a multi-year sequence of technology use so that students gradually became more fluent. Most schools do not have teachers with the same group of students over multiple years; however, teachers can share projects that they have had students complete so that teachers in other grade levels have an idea as to the students' skill levels. Additionally, schools could create a technology sequence plan to help build students' skills. As seen in this research, the technology plan may have to be individual to each student population, as students can enter school with vastly different abilities depending on their access to technology at home. Classroom climates that promote a high level of trust between the teacher and the students may encourage teachers to put technology in students' hands more frequently.

\section{Professionalism}

This research indicates that on-going training and support is important, even for technology savvy teachers. The teachers' attitudes of curiosity and willingness to learn new equipment and applications of technology clearly made a difference in this study. As teachers encounter new equipment and programs they may need training. New educational uses for technology, such as technology that teachers already use in their personal lives, may require support in developing how to use it with students. Teachers need help, not just in knowing how to use the technology, but also in how to introduce it to the students and for what educational purposes it can be used. Training or support for technology use needs to be ongoing, hands-on, and differentiated to the needs of the teachers. Professional learning communities for teachers can be on-going across the school year, and need not be limited by distance between schools when email, chat rooms, discussion threads, or other Internet tools are used.

New teachers coming through pre-service teacher programs will primarily have been educated in classrooms that had at least some technology. Pre-service teacher programs need to demonstrate the meaningful ways that technology can be used in the classroom and provide opportunities for pre-service teachers to experience technology both from a student and a teacher perspective.

\section{Limitations and Further Study}

Many possible research projects follow from this descriptive study. More qualitative phenomenological multi-case studies should be conducted with participant teachers to broaden the de- 
mographics of those studied. Studying teachers from other certification programs, teachers who work in other states, and teachers who do not use technology as frequently would provide good comparison data. This study was done with elementary school G/T teachers. Secondary schools are likely to have different curriculum and scheduling requirements, as well as differences in access to equipment.

This research is done from a teacher perspective. To gain further information about the phenomena of students' educational technology experiences, research needs to be done that focuses on the perspective of the students. This research would necessarily include participants who are students.

\section{Conclusion}

Though technology is prevalent in culture today, students still need teachers to help them develop a robust understanding of the potential of technology to go beyond the more casual usage developed at home. Teachers providing G/T services, due to their freedom in determining curriculum and their multiyear relationship with students, are in a prime position to develop students' technology literacy. Students need help developing the $21^{\text {st }}$ century skills that will make technology an effective tool rather than just a play toy.

The fast pace development of technology and educational applications potentially create similar development of pedagogy. Surveys and questionairres are insufficient to provide information about these phenomena. Qualitative research methods, such as this research study, add to the body of knowledge about education technology because it provides a picture of what is already occurring in classrooms. As shown in this qualitative study, development of technology-literacy for students is impacted by the characteristics of the teacher, the equipment, the pedagogy, and the characteristics of the students.

\section{References}

Abelman, R. (2007). Figthing the war on indecency: Mediating TV, Internet, and videogame usage among achieveing and underachieving gifted children. Roeper Review, 29, 100-112.

Angeli, C., \& Valanides, N. (2009). Epistemological and methodological issues for the conceptualization, development, and assessment of ICT-TPCK: Advances in technological pedagogical content knowledge (TPCK). Computers \& Education, 52(1), 154-168.

Ba, H., Tally, W., \& Tsikalas, K. (2002). Investigating children's emerging digital literacies. The Journal of Technology, Learning and Assessment, 1(4). Retrieved from http://escholarship.bc.edu/jtla/vol1/4/

Basham, J. D., Meyer, H., \& Perry, E. (2010). The design and application of the digital backpack. Journal of Research on Technology in Education, 42(4), 339-359.

Baule, S. M. (2007). The components of successful technology. Teacher Librarian, 34(5), 16-18.

Bebell, D., O’Dwyer, L. M., Russell, M., \& Hoffmann, T. (2010). Concerns, considerations, and new ideas for data collection and research in educational technology studies. Journal of Research on Technology in Education, 43, 29-52.

Bebell, D., Russell, M., \& O'Dwyer, L. (2004). Measuring teachers' technology uses: Why multiplemeasures are more revealing. Journal of Research on Technology in Education, 37, 45-63.

Bielefeldt, T. (2012). Guidance for technology decisions from classroom observation. Journal of Research on Technology in Education, 44, 205-223.

Boon, R. T., Fore, C., \& Rasheed, S. (2007). Students' attitudes and perceptions toward technology-based applications and guided notes instruction in high school world history classrooms. Reading Improvement, 4(1), 23-31. 
Bucci, T. T. (2003). The technology teaching lab: Meeting the ISTE challenge. Action in Teacher Education, 24(4), 1-9.

Chai, C.-S., Koh, J. H..-L., \& Tsai, C.-C. (2013). A review of technological pedagogical content knowledge. Educational Technology \& Society, 16(2), 31-51.

Clark, W., Logan, K., Luckin, R., Mee, A., \& Oliver, M. (2009). Beyond Web 2.0: mapping the technology landscapes of young learners. Journal of Computer Assisted Learning, 25(1), 56-69. doi: 10.1111/j.1365-2729.2008.00305.x

Clarke-Midura, J., \& Dede, C. (2010). Assessment, technology, and change. Journal of Research on Technology in Education, 42, 309-328.

Clausen, J. M. (2007). Beginning teachers' technology use: First-year teacher development and the institutional context's affect on new teachers' technology use with students. Journal of Research on Technology in Education, 39, 245-261.

Couse, L. J., \& Chen, D. W. (2010). A tablet computer for young children? Exploring its viability for early childhood education. Journal of Research on Technology in Education, 43(1), 75-98.

Creswell, J. W. (2007). Qualitative inquiry and research design: Choosing among five approaches (2nd ed.). Thousand Oaks, CA: Sage Publications, Inc.

Donovan, L., Hartley, K., \& Strudler, N. (2007). Teacher concerns during initial implementation of a oneto-one laptop initiative at the middle school level. Journal of Research on Technology in Education, $39,263-286$.

Dove, M. K., \& Zitkovich, J. A. (2003). Technology driven group investigations for gifted elementary students. Information Technology in Childhood Education Annual, 2003(1), 223-241.

Elstad, E. (2008). Building self-discipline to promote learning: students' volitional strategies to navigate the demands of schooling. Learning Inquiry, 2(1), 53-71.

Eshet-Alkalai, Y. (2004). Digital Literacy: A Conceptual Framework for Survival Skills in the Digital Era. Journal of Educational Multimedia and Hypermedia, 13(1), 93-106.

Fleming, L., Motamedi, V., \& May, L. (2007). Predicting preservice teacher competence in computer technology: Modeling and application in training environments. Journal of Technology and Teacher Education, 15, 207-231.

Garcia, P., \& Rose, S. (2007). The influence of technocentric collaboration on preservice teachers' attitudes about technology's role in powerful learning and teaching. Journal of Technology and Teacher Education, 15, 247-266.

Ge, X., Thomas, M. K., \& Greene, B. A. (2006). Technology-rich ethnography for examing the transition to authentic problem-solving in a high school computer programming class. Journal of Education Computing Research, 34(4), 319-352.

Glassman, M., \& Burbidge, J. (2014). The dialectical relationship between place and space in education: How the Internet is changing our perceptions of teaching and learning. Educational Theory, 64(1), 1532.

Gregory, A. \& Ripski, M. B. (2008). Adolescent trust in teachers: Implications for behavior in the high school classroom. School Psychology Review, 37(3), 337-353.

Hall, G. E. (2010). Technology's Achilles heel: Achieving high-quality implementation. Journal of Research on Technology in Education, 42, 231-253.

Hodges, C. B., \& Prater, A. H. (2014). Technologies on the horizon: Teachers response to the Horizon Report. TechTrends, 58(3), 71-78.

Housand, B. C. (2011, July 2011). Gifted education in the 21st century: A new hope. Paper presented at the Edufest, Boise, Idaho. 
International Society for Technology in Education. (2010). Standards for global learning in the digital age. Retrieved from http://www.iste.org/standards.aspx

Johnsen, S. K., Witte, M., \& Robins, J. (2000). Through their eyes: Students' perspectives of a universitybased enrichment program - The University for Young People Project. Gifted Child Today, 29(3), 5661.

Kang, M., Heo, H., Jo, I.-H., Shin, J., \& Seo, J. (2010). Developing an educational performance indicator for new millennium learners. Journal of Research on Technology in Education, 43, 157-170.

Katic, E. K. (2008). Preservice teachers' conceptions about computers: an ongoing search for transformative appropriations of modern technologies. Teachers \& Teaching, 14(2), 157-179. doi: $10.1080 / 13540600801983344$

Ke, F. (2008). A case study of computer gaming for math: Engaged learning from gameplay? Computers \& Education, 51(4), 1609-1620. doi: 10.1016/j.compedu.2008.03.003

Kimball, K. L. B. (2001). Interpretative stories from school careers of gifted students. ProQuest database. (AAT 3032075).

Koehler, M. J., \& Mishra, P. (2005). What happens when teachers design educational technology? The development of technoligical pedagogical content knoweldge. Journal of Educational Computing Research, 32(2), 131-152.

Lagrange, J.-B., \& Erdogan, E. O. (2009). Teachers' emergent goals in spreadsheet-based lessons: analyzing the complexity of technology integration. Educational Studies in Mathematics, 71(1), 65-84. doi: 10.1007/s10649-008-9160-2

Lowther, D. L., Inan, F. A., Ross, S. M., \& Strahl, J. D. (2012). Do ont-to-one initiatives bridge the way to $21^{\text {st }}$ century knowledge and skills? Journal of Educational Computing Research, 26(1), 1-30.

Lye, S. Y., Abas, S., Tay, L. Y., \& Saban, F. (2012). Exploring the use of onliny space in an elementary school. Educational Media International, 49(3), 155-170.

Marshall, C., \& Rossman, G. B. (2011). Designing qualitative research (5th ed.). Los Angeles, CA: Sage.

Merriam, S. B. (1988). Case Study Research in Education. San Francisco, CA: Jossey-Bass Inc.

Mostow, J., Nelson-Taylor, J., \& Beck, J. E. (2013). Computer-guided oral reading versus independent practice: Comparison of sustainsilent reading to an automated readign tutor that listens. Journal of Educational Computing Research, 49, 249-276.

Myles, B. S., Ferguson, H., \& Hagiwara, T. (2007). Using a personal digital assistant to improve the recording of homework assignments by an adolescent with Asperger Syndrome. Focus on Autism and Other Developmental Disabilities, 22(2), 96-99.

National Assessment Governing Board. (n.d.). Technology and Engineering Literacy Framework for the 2014 NAEP. Retrieved from http://www.nagb.org/publications/frameworks/technology/2014technology-framework.html

National Association for Gifted Children/Council for Exceptional Children. (2006). Initial knowledge and skill standards for gifted and talented education. Retrieved from http://www.cectag.org

National Association for Gifted Children. (2010). 2010 Pre-K-Grade 12 Programming Standards. Retrieved from http://www.nagc.org.442elmp01.blackmesh.com/sites/default/files/standards/K$12 \% 20$ programming $\% 20$ standards.pdf

National Council for Accreditation of Teacher Education. (2012). Unit standards in effect 2008. Retrieved from http://www.ncate.org/Standards/NCATEUnitStandards/UnitStandardsinEffect2008/tabid/476/Default.a $\underline{\mathrm{spx}}$

Neuman, S. B., \& Celano, D. (2006). The knowledge gap: Implications of leveling the playing field for low-income and middle-income children. Reading Research Quarterly, 41, 176-201. 
Nugent, G., Barker, B., Grandgenett, N., \& Adamchuk, V. I. (2010). Impact of robotics and geospatial technology interventions on youth STEM learning and attitudes. Journal of Research on Technology in Education, 42(4), 391-408.

Olszewski-Kubilius, P., \& Lee, S. Y. (2004). Gifted adolescents' talent development through distance learning. Journal for the Education of the Gifted, 28(1), 7-35.

Partnership for 21st Century Skills. (2004). Framework for 21st Century Learning. Retireved from http://www.p21.org/index.php?option=com_content\&task=view\&id=254\&Itemid=120

Partnership for 21st Century Skills, \& American Association of Colleges of Teacher Education. (2010). 21 st century knowledge and skills in educator preparation. Retrieved from http://www.p21.org/storage/documents/aacte_p21_whitepaper2010.pdf

Penhasi-Vittorio, L. \& Ben-Yosef, E. (2014). A quest for re-scripting the narrative of education failure: Initial steps in a journey. Radical Pedagogy 11(1). Retrieved from http://www.radicalpedagogy.org/radicalpedagogy.org/A_Quest_for_ReScripting the_Narrative_of_Education_Failure_Initial_Steps_in_a_Journey.html

Perrotta, C. (2013). Do school-level factors influence the education benefits of digital technology? A critical analysis of teachers' perceptions. British Journal of Educational Technology, 44, 314-327. doi: 10.1111/j.1467-8535.2012.01304.x

Reid, P. T., \& Roberts, S. K. (2006). Gaining options: A mathematics program for potentially talented atrisk adolescent girls. Merrill-Palmer Quarterly, 52, 288-304.

Ritzhaupt, A. D., Dawson, K., \& Cavanaugh, C. (2012). An investifation of factors influencing student use of technology in K-12 classrooms using path analysis. Journal for Educational Computing Research, 46, 229-254.

Rowley, J., Dysard, G., \& Arnold, J. (2005). Developing a new technology infusion program for preparing tomorrow's teachers. Journal of Technology and Teacher Education, 13, 105-123.

Savannah R-III School District. (2001). Case study: Savannah R-III School District. T.H.E. Journal, 29(3), 66.

Shaunessy, E. (2007). Attitudes toward information technology of teachers of the gifted: Implications for gifted education. Gifted Child Quarterly, 51, 119-135.

Siegle, D. (2004). The merging of literacy and technology in the 21st century: A bonus for gifted education. Gifted Child Today, 27(2), 32-35.

Siegle, D. (2005). Six uses of the Internet to develop students' talents and gifts. Gifted Child Today, 28(2), 30-36.

Siegle, D., \& Foster. (2001). Laptop computers and multimedia and presentation software: Their effects on student achievement in anatomy and physiology. Journal of Research on Technology in Education, 34, 29-37.

Smith, J. A., \& Osborn, M. (2004). Interpretative Phenomenological Analysis. In G. M. Breakwell (Ed.), Doing Social Psychology Research (pp. 229-254). Malden, MA: British Psychological Society Blackwell.

Snider, S. L. (2002). Exploring technology integration in a field-based teacher education program: Implementation efforts and findings. Journal of Research on Technology in Education, 34, 230-249.

Tünzün, H. (2007). Blending video games with learning: Issues and challenges with classroom implementations in the Turkish context. British Journal of Educational Technology, 38, 465-477.

Wade, W. Y., Rasmussen, K. L., \& Fox-Turnbull, W. (2013). Can technology be a transformative force in education? Preventing School Failure, 57(3), 162-170.

Wighting, M. J. (2006). Effects of computer use on high school students' sense of community. The Journal of Educational Research, 99, 371-379. 
Wilson, E. K., Wright, V. H., \& Stallworth, B. J. (2003). Secondary preservice teachers' development of electronic portfolios: An examination of perceptions. Journal of Technology and Teacher Education, $11,515-527$.

Wong, A. F. L., Quek, C. L., Divaharan, S., Liu, W. C., Peer, J., \& Williams, M. D. (2006). Singapore students' and teachers' perceptions of computer-supported project work classroom learning environments. Journal of Research on Technology in Education, 38, 449-479.

Ysseldyke, J., Tardrew , S., Betts, J., Thill, T., \& Hannigan, E. (2004). Use of an instructional management system to enhance math instruction of gifted and talented students. Journal for the Education of the Gifted, 27, 293-310.

Zembal-Saul, C., Krajcik, J., \& Blumenfeld, P. (2002). Elementary student teachers' science content representations. Journal of Research in Science Teaching, 39(6), 443-463.

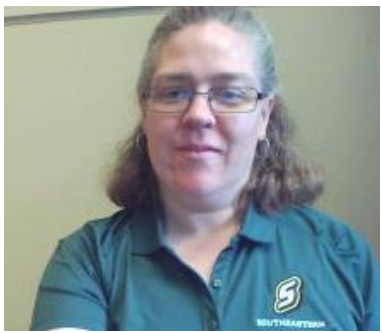

\section{Biography}

Susan L. Zimlich, Ph.D. taught for several years in elementary school enrichment for students identified as gifted. She eventually found her way to a doctoral program for special education emphasizing gifted education. She currently is an assistant professor of elementary and middle school science and social studies methods, teaching undergraduates and she teaches graduates working on academically gifted certification. 